\title{
Sedentary Behavior Among School-aged Students During Pandemic: A Cross-Sectional Study
}

\author{
Rizky Maulana ${ }^{1,}$ Yetty Septiani Mustar ${ }^{2, *}$ Anindya Mar'atus Sholikhah ${ }^{3,}$ \\ Bayu Agung Pramono ${ }^{4}$ Indra Himawan Susanto ${ }^{5}$ \\ 1,2,3,5 Department of Health Education and Recreation, Universitas Negeri Surabaya, Surabaya, Indonesia \\ ${ }^{4}$ Department of Sport Coaching Education, Universitas Negeri Surabaya, Surabaya, Indonesia \\ *Corresponding author.Email: yettymustar@unesa.ac.id
}

\begin{abstract}
It is well established that sedentary behavior is associated with obesity, quality of life, all-cause, and cardiovascular death. Along with the COVID-19 pandemic, sedentary behavior is increasing. This study aims to describe sedentary activity among school-aged children. Participants of this study were 67 students, 30 boys and 37 girls. Data collected in the present study from Adolescent Sedentary Activity Questionnaire (ASAQ) filled by the participants about their sedentary behavior. This cross-sectional study revealed that most sedentary behavior among children was playing smartphones or tablets in their spare time $(8.59 \pm 5.93)$ hours on weekdays, while on weekends, $(3.95 \pm 3.41)$ hours. There was no significant difference regarding characteristics (age, height, weight, and BMI) and sedentary behavior between males and females. Besides, a significant correlation was found in the study-based activities on the weekend with age and other sedentary activities on BMI. This prolonged sedentary behavior among children could be the leading cause of obesity, which later can develop into a chronic disease. It is imperative to limit sedentary behavior by involving their parents and developing programs to promote physical activity engagement.
\end{abstract}

Keywords: Sedentary lifestyle, Children, Screen time, Pandemic

\section{INTRODUCTION}

It is undeniable that technological developments have increased, especially since the world entered the industrial revolution 4.0 [1]. Technology plays an essential role as a provider of information and communication in the current period, where gadgets are technologies almost everyone widely uses. Gadgets are becoming increasingly sophisticated technology along with the development of the Internet of Things (IoT), in which touchscreen-based gadgets are equipped with various kinds of social networking applications, entertainment, and other exciting things [2]. Although it can have a positive impact, technology can also hurt its user [3]. The nature of its users that can provide easy access can be something that can cause a sense of laziness in oneself [4].

Lazy behavior or lack of movement is known as sedentary behavior (SB). Sedentary behavior is a variety of behaviors characterized by low energy use or less than 1.5 metabolic equivalents (METs), including sitting and lying activities [5]. Recent studies have used inactive to describe people who do moderate or vigorous physical exercise (MVPA) in insufficient amounts. That is, they do not meet the physical activity guidelines [6]. According to Chaput et al. [7], sedentary behavior includes using smartphones or tablets, watching TV, playing video games, using computers, driving or driving a car, and reading or studying while sitting.

Sedentary behavior is now increasing along with the Covid-19 pandemic [8]. This is in line with research conducted by Bates et al. [9], where this pandemic impact changes in lifestyle activities in children for 24 hours/day. The effects of sedentary behavior such as watching television, using the computer, or playing games together, which is referred to as screen time, have become a particular focus that negatively impacts health [10]. Children's time using digital devices is increasing rapidly along with the development of new portable and instantly accessible technologies such as smartphones and digital tablets [11]. The previous studies also showed an increase in screen time activity, especially among students during this pandemic [12]. This habit also contributed to decreased physical activity and increased 
sedentary behavior in the pediatric population [13].

Most of the research conducted during the Covid-19 pandemic showed a global decline in physical activity in children and adolescents [14]. In many countries, the rising number of insufficient physical activities has significant implications for the increasing prevalence of non-communicable diseases affecting general health [15]. Some adverse health effects are increased mortality, cardiovascular disease, cancer risk, diabetes mellitus risk, hypertension, dyslipidemia, osteoporosis, depression, and cognitive impairment [16]. Lifestyle-related diseases are infrequent in children, but many chronic diseases in adulthood begin with childhood habits and lifestyles [17]. Prolonged time for screen-based activities among children is one of the risk factors of chronic disease [18]. In addition, excessive screen time also inhibits children's growth and development, reduces brain performance, and disrupts sleep patterns due to the impairment of sleep duration and quality [19].

Studies related to sedentary behavior and its health risks in children and adolescents become of great interest, especially during a pandemic. Given the potential increased risk of obesity which later can develop into chronic diseases due to prolonged sedentary behavior, it is essential to gather data regarding the impact of the covid-19 pandemic on children's physical inactivity. Thus, we conduct this research to describe the sedentary activity in school-aged children. It can provide broad information to develop programs and policies to promote children's willingness to engage the insufficient level of PA facing the new normal.

\section{METHODS}

\subsection{Study design and participants}

This descriptive quantitative research used a survey method. Conducted in June - July 2021. The population in this sample is elementary school students in Surabaya. The sampling technique used purposive sampling with inclusion criteria: 1) the sample is elementary school students; 2) 10 - 11 years old, 3) currently taking Physical Education and Health subjects. A total of 67 students participated in this study.

\subsection{Data collection}

Data was collected by distributing questionnaires filled out by respondents online through a google form. The data collected includes essential characteristics and sedentary activities on weekdays and weekends. The sedentary activity was measured using a self-reported questionnaire using the Adolescent Sedentary Activity Questionnaire (ASAQ) [20]. This validated questionnaire consists of 10 questions: $1-3$ questions related to screen- based activities, $4-6$ study-based activities, and $7-10$ other sedentary activities.

\subsection{Statistical analysIs}

Data were collected, cleaned, and processed using IBM Statistic SPSS 21 application software. Data were analyzed descriptively by displaying the mean and standard deviation for each measured sedentary behavior item. Furthermore, data were analyzed using MannWhitney to compare sedentary activity on weekdaysweekends and to measure the association of sedentary behavior between age and BMI; Spearman rank correlation coefficient analysis was used, and the significance level $(\mathrm{p}$-value $)<0.05$.

\section{RESULTS}

Characteristics of participants from a total of 67 students showed that most of the participants were male $55.2 \%, 11$ years old 59.7\%, and BMI/A in the normal category $86.5 \%$ (Table 1 ).

Table 1. Characteristic of participant

\begin{tabular}{|l|c|c|}
\hline \multirow{2}{*}{ Characteristic } & \multicolumn{2}{c|}{$n=67$} \\
\cline { 2 - 3 } & $n$ & $\%$ \\
\hline Gender & 37 & 55.2 \\
\hline Male & 30 & 44.8 \\
\hline Female & 27 & 40.3 \\
\hline Age (years) & 40 & 59.7 \\
\hline 10 & 58 & 86.5 \\
\hline 11 & 4 & 6 \\
\hline BMI/A & 5 & 7.5 \\
\hline Normal & \multicolumn{2}{|c}{} \\
\hline Overweight & \multicolumn{1}{|c|}{} \\
\hline Obese &
\end{tabular}

Furthermore, the total average daily sedentary time of children based on the self-reported results showed that the average time children spent on sedentary behavior during weekdays and weekends were $4.93 \pm 3.10$ hours/day and $5.68 \pm 3.03$ hours/day, respectively (Figure 1). In detail, the average time spent by participants doing sedentary behavior activities during weekdays (Monday - Friday) and weekends (Saturday Sunday) are presented in Table 3. The most sedentary behavior carried out by children was playing smartphones or tablets in their spare time, which was 8.59 (5.93) hours on weekdays, while on weekends was 3.95 (3.41) hours. Meanwhile, the lowest sedentary activity or behavior carried out was playing computer in free time, 0.50 (0.91) hours on weekdays, and weekends, using computers in doing tasks, which was 0.22 (0.27) hours. 


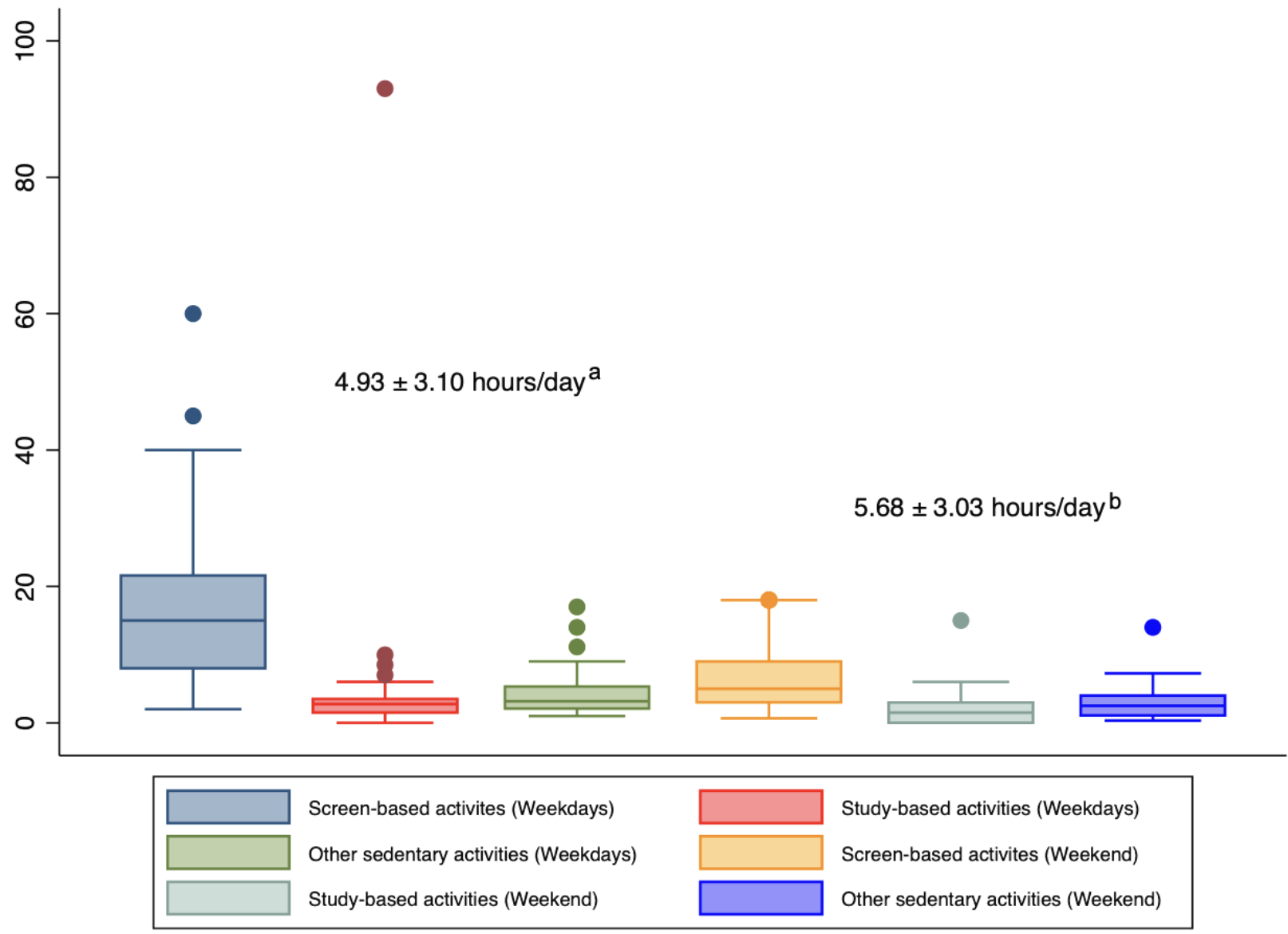

Figure 1 Self-reported the average daily sedentary time among children Data are presented as mean (SD) a $\mathrm{SB}$ during weekdays, bS during weekend

Table 2. Self-administrated sedentary behavior among children

\begin{tabular}{|c|c|c|c|c|c|}
\hline \multirow{3}{*}{ No } & \multirow{3}{*}{ Items } & \multicolumn{4}{|c|}{$n=67$} \\
\hline & & \multicolumn{2}{|c|}{ Weekdays } & \multicolumn{2}{|c|}{ Weekend } \\
\hline & & Mean & SD & Mean & SD \\
\hline \multicolumn{6}{|c|}{ Screen-based activities } \\
\hline 1. & Television or video viewing & 7.35 & 7.90 & 2.15 & 2.10 \\
\hline 2. & Playing for recreation or leisure on a cell phone or tablet & 8.59 & 5.93 & 3.95 & 3.41 \\
\hline 3. & Playing for recreation or leisure on a computer & 0.50 & 0.91 & 0.38 & 0.77 \\
\hline \multicolumn{6}{|c|}{ Study-based activities } \\
\hline 4. & Computer use for homework & 1.98 & 1.09 & 0.22 & 0.57 \\
\hline 5. & Doing homework not using computer & 1.34 & 1.27 & 0.86 & 0.89 \\
\hline 6. & Attending extracurricular classes & 0.85 & 0.73 & 0.90 & 1.60 \\
\hline \multicolumn{6}{|c|}{ Other sedentary activities } \\
\hline 7. & Reading for fun or interest & 1.09 & 1.09 & 0.85 & 0.83 \\
\hline 8. & Transportation by car or bus or train & 0.94 & 1.02 & 0.47 & 0.54 \\
\hline 9. & Talking on the phone or sit around & 0.64 & 0.68 & 0.63 & 0.96 \\
\hline 10. & $\begin{array}{l}\text { Others such as practicing musical calligraphy/ painting, making crafts, } \\
\text { listening to music, etc }\end{array}$ & 1.32 & 1.96 & 0.92 & 0.92 \\
\hline
\end{tabular}

Subsequently, the Mann-Whitney test was performed to evaluate further the differences in characteristics and sedentary behavior between gender (Table 3). Surprisingly, our statistical test results showed no significant difference regarding characteristics (age, height, weight, and BMI) and sedentary behavior (screenbased, study-based, and other sedentary activities) between males and females ( $p$-value $>0.05$ ). 
Table 3. Difference of characteristic and sedentary behavior between gender

\begin{tabular}{|c|c|c|c|}
\hline \multirow{3}{*}{ Variables } & \multicolumn{2}{|c|}{$N=67$} & \multirow{3}{*}{ p-value } \\
\hline & Girls & Boys & \\
\hline & Mean (SD) & Mean (SD) & \\
\hline \multicolumn{4}{|l|}{ Characteristic } \\
\hline Age, years & $10.6(0.50)$ & $10.59(0.50)$ & 0.964 \\
\hline Height $(\mathrm{cm})$ & $142.67(8.80)$ & $143.54(9.37)$ & 0.723 \\
\hline Weight (kg) & $35.23(6.79)$ & $40.19(10.5)$ & 0.081 \\
\hline $\mathrm{BMI}$ & $17.24(2.59)$ & $19.28(4.03)$ & 0.052 \\
\hline \multicolumn{4}{|l|}{ Sedentary behavior, hours/week } \\
\hline Screen-based activities & $21.53(12.75)$ & $24.10(13.04)$ & 0.395 \\
\hline Weekday & $15.83(11.40)$ & $16.97(10.46)$ & 0.596 \\
\hline Weekend & $5,70(4.11)$ & $7.14(5.16)$ & 0.260 \\
\hline Study-based activities & $7.83(16.41)$ & $4.85(3.78)$ & 0.449 \\
\hline Weekday & $5.78(16.54)$ & $2.90(2.27)$ & 0.686 \\
\hline Weekend & $2.05(1.52)$ & $1.96(2.73)$ & 0.259 \\
\hline Other sedentary activities & $6.89(4.61)$ & $6.87(3.87)$ & 0.733 \\
\hline Weekday & $3.85(3.03)$ & $4.13(2.84)$ & 0.614 \\
\hline Weekend & $3.05(2.75)$ & $2.75(1.78)$ & 0.925 \\
\hline
\end{tabular}

Data presented as mean (SD), $B M I$ - body mass index, *significant $p$-value $<0.05$

Table 4. Correlation of screen-based, study-based, and other sedentary activities between age and BMI

\begin{tabular}{|l|c|c|c|c|}
\hline \multirow{2}{*}{ Characteristic } & \multicolumn{4}{|c|}{$\mathrm{n}=67$} \\
\cline { 2 - 5 } & \multicolumn{2}{|c|}{ Age (years) } & \multicolumn{2}{c|}{ BMI } \\
\cline { 2 - 5 } & p-value & $r$ & p-value & $r$ \\
\hline Screen-based activities \\
\hline Weekdays & 0.899 & 0.016 & 0.934 & -0.010 \\
\hline Weekend & 0.780 & -0.035 & 0.581 & 0.069 \\
\hline Study-based activities \\
\hline Weekdays & 0.481 & -0.088 & 0.845 & 0.024 \\
\hline Weekend & $0.040^{*}$ & -0.251 & 0.627 & 0.060 \\
\hline Other sedentary activities \\
\hline Weekdays & 0.539 & 0.076 & 0.107 & 0.198 \\
\hline Weekend & 0.980 & -0.003 & $0.010^{*}$ & 0.313 \\
\hline
\end{tabular}

*significant $p$ value $<0.05$

Spearman's Rank correlation test suggested a weak inverse correlation between study-based activities on weekends with age $(\mathrm{p}=0.040 ; \mathrm{r}=-0.251)$. The present study also found that another sedentary activity was positively associated with BMI $(\mathrm{p}=0.010 ; \mathrm{r}=0.313)$.

\section{DISCUSSION}

Sedentary behavior is a public health concern [21]. Sedentary can also be defined as behavior performed with little or no energy expenditure in a sitting or lying position [22]. Watching television, reading books, playing gadgets, and lack of moving activities are included in sedentary behavior [23]. In general, sedentary behavior is mainly done by adults and the elderly who spend most of their time working in prolonged sitting positions. However, sedentary behavior is currently spreading among elementary school-aged children to young adolescents.
The present study indicates that the most sedentary behaviour carried out by children was screen-based activities such as watching television or videos, playing smartphones or online games, tablets, or computers [24]. Previous research has also shown that school-age children most frequently do screen-based activities, but this research was conducted before the COVID-19 pandemic, which was at least 1 hour/day and increased on holidays, which was 2 hours/day [25]. According to the Australian Government Department of Health [26], the recommended recommendation is not to exceed 2 hours/day. In addition, the Public Health Official has also suggested that children should not engage in sedentary activities for more than 1 hour at a time [27]. The Canadian 24 Hour Movement Guidelines for Children and Youth limit this activity to 2 hours/day [28]. Based on these data, the use of the time that is mainly used for screen-based activities can have a negative impact on children's health if it exceeds the recommended usage limit. Furthermore, the interest and culture of children's literacy or reading are very minimal compared to doing screen-based activities. This can be seen from the results of previous studies, where the decrease in the quality of learning and the increase in screen-based activity will affect children's academic and cognitive abilities [29].

Technological developments and the impact of the Covid-19 pandemic have affected children's sedentary behavior. Several previous studies believe that the pandemic is the cause of decreased physical activity and increased sedentary behavior, so further action is needed to prevent this impact [30]. According to Pangesti et al. [31], the causes of children being lazy to do physical activities and choosing sedentary behavior are limited playing fields, inadequate sports facilities, and technological advances. The family environment can also 
be the cause of the child doing a lot of sedentary activities. The high percentage of time spent on sedentary behavior during the period of time children might pay with their parents (time outside of school and on weekends) reinforces the fact that the family environment is an essential modulator of children's behavior [32]. The most vital relationship between parent and child is when parent and child are always sided by the side (i.e., the child is not in daycare or being cared for by another adult). In this case, there is a positive relationship where the more active the parents are, the more active the child will be, and vice versa; the more parents engage in sedentary behavior, the more children will do the same thing [33].

Increasing sedentary behavior will indirectly reduce energy expenditure, which is a health risk factor. Unhealthy lifestyles such as lack of movement and lack of physical activity can lead to fat accumulation in the body and not released as energy. If this condition lasts for a long time, it can cause expansion in the abdominal area, interfering with the body's metabolism. Prolonged sitting also contributes to less energy expenditure; if it lasts for a long time, it can lead to weight gain, which develops into obesity hypertension later in life [34]. Children aged 7-18 years with sedentary behavior for 1-2 hours and $>2$ hours have 1.64 times and 1.94 times chance of being obese [35]. In Canada, children who are overweight and obese are on the rise, and they consistently do not meet the recommended guidelines for limiting sedentary (no more than 2 hours/day of screen-based activity time) [36]. Sedentary behavior has a relationship with health conditions, including mental health, obesity, type 2 diabetes mellitus, cardiovascular disease, and breast, colorectal, endometrial, and ovarian cancers [36]. In addition, sedentary behavior also has a negative impact on mental health, namely anxiety disorders and depression [37], [38]. In another study, sedentary behavior can also increase the risk of insomnia and sleep disturbances [39]. The threshold in sedentary activities such as sitting is 6-8 hours/day, and watching TV activities as much as 3-4 hours/day, above that can negatively impact health more quickly [40]. Some facts about health risks that have occurred illustrate that sedentary behavior is an activity that is not good for the health of the body. Further scrutiny regarding early intervention is necessary in order to minimize the risk of this sedentary behavior.

Sedentary behavior is often associated with physical activity, which is related to energy in the body. Good physical activity has many health benefits for the body, including skeletal and cardiovascular muscle health, bodyweight health and the muscular, nervous system, the quality of the coordination system, and movement control [41]. The World Health Organization (WHO) recommends that children and adolescents aged 5-17 years are advised to do 60 minutes of physical activity/day where the frequency of activity in 1 week can be done three times. Physical activity is a preventive measure to anticipating sedentary behavior, especially during the COVID-19 pandemic; it is highly recommended [42].

\section{CONCLUSION}

The present study showed that the sedentary behavior among elementary school-age children exceeds the recommended limit that has been set with the average time children spent on sedentary behavior during weekdays $4.93 \pm 3.10$ hours/day and weekends $5.68 \pm$ 3.03 hours/day. The results of this study can be used as baseline data related to sedentary activity patterns in children during the pandemic so that future programs are expected to increase physical activity among children, which is no more than 2 hours/day. Prolonged time in sedentary negatively impacts health. The role of parents is essential to limit sedentary behavior among children, and increasing physical activity is highly recommended to prevent children from various health risks.

\section{REFERENCES}

[1] Sumargiyani, I. T. R. Yanto, and R. Hamzah, "Application of Learning Models Technology In The 4.0 Industry Era In Basic School," Jurnal Berdaya Mandiri, vol. 3, no. 1, pp. 468-475, 2021.

[2] D. Aviani, L. Latiana, and Mulawarman, "Dampak Gaya Pengasuhan Permisif Terhadap Penggunaan Gadget Pada Anak," Prosiding Seminar Nasional Pascasarjana UNNES, pp. 68-74, 2020.

[3] I. N. Imamah and D. Rahmawatie, "Anak Hebat Tanpa Gadget di SDN Pabelan 02 Kartasuro," Gemassika, vol. 3, no. 1, pp. 60-68, 2019.

[4] A. Hudaya, "Pengaruh Gadget Terhadap Sikap Disiplin dan Minat Belajar Peserta Didik," Research and Development Journal Of Education, vol. 4, no. 2, pp. 86-97, 2018.

[5] A. Stephenson, S. M. Mcdonough, M. H. Murphy, C. D. Nugent, and J. L. Mair, "Using a computer, mobile and wearable technology-enhanced interventions to reduce sedentary behavior: a systematic review and meta-analysis," International Journal of Behavioral Nutrition and Physical Activity, vol. 14, p. 105, 2017, DOI: 10.1186/s12966-017-0561-4.

[6] H. P. Van Der Ploeg and M. Hillsdon, "Is sedentary behavior just physical inactivity by another name?," International Journal of Behavioral Nutrition and Physical Activity, vol. 14, no. 142, pp. 1-8, 2017, DOI: 10.1186/s12966-017-0601-0.

[7] J. Chaput et al., "2020 WHO guidelines on physical activity and sedentary behavior for children and adolescents aged 5-17 years: summary of the evidence," International Journal of Behavioral Nutrition and Physical Activity, vol. 17, pp. 1-9, 2020.

[8] S. Stockwell et al., "Changes in physical activity and sedentary behaviors from before to during the 
COVID-19 pandemic lockdown: A systematic review," BMJ Open Sport and Exercise Medicine, vol. 7, no. 1, pp. 1-8, 2021, DOI: 10.1136/bmjsem2020-000960.

[9] L. C. Bates et al., "COVID-19 Impact on Behaviors across the 24-Hour Sedentary Behavior, and Sleep," Children, vol. 7, no. 138, pp. 1-9, 2020.

[10] C. M. Nightingale et al., "Screen time is associated with adiposity and insulin resistance in children," Archives of Disease in Childhood, vol. 102, no. 7, pp. 612-616, 2017, DOI: 10.1136/archdischild2016-312016.

[11] R. Hosokawa and T. Katsura, "Association between mobile technology use and child adjustment in early ele," Plos one, vol. 13, no. 7, pp. 1-17, 2018.

[12] P. Ganne, S. Najeeb, G. Chaitanya, and A. Sharma, "Digital Eye Strain Epidemic amid COVID-19 Pandemic - A Cross-sectional Survey," Ophthalmic Epidemiology, vol. 28, no. 4, pp. 285-292, 2021, DOI: $10.1080 / 09286586.2020 .1862243$.

[13] T. Štveráková, J. Jačisko, A. Busch, M. Šafářová, P. Kolár̆, and A. Kobesová, "The impact of COVID19 on Physical Activity of Czech children.," PloS one, vol. 16, no. 7, pp. 1-4, 2021, doi: 10.1371/journal.pone.0254244.

[14] A. Rodríguez-Larrad et al., "Impact of COVID-19 confinement on physical activity and sedentary behaviour in Spanish university students: Ole of gender," International Journal of Environmental Research and Public Health, vol. 18, no. 2, pp. 114, 2021, DOI: 10.3390/ijerph18020369.

[15] F. Ricci et al., "Recommendations for Physical Inactivity and Sedentary Behavior During the Coronavirus Disease ( COVID-19 ) Pandemic," Frontiers in Public Health, vol. 8, no. May, pp. 811, 2020, DOI: 10.3389/fpubh.2020.00199.

[16] J. H. Park, J. H. Moon, H. J. Kim, M. H. Kong, and Y. H. Oh, "Sedentary Lifestyle: Overview of Updated Evidence of Potential Health Risks," Korean Journal of Family Medicine, vol. 41, no. 6, pp. 365-373, 2020, DOI: 10.4082/KJFM.20.0165.

[17] B. Bringolf-Isler et al., "Sedentary Behaviour in Swiss Children and Adolescents: Disentangling Associations with the Perceived and Objectively Measured Environment," International Journal of Environmental Research and Public Health, vol. 15, pp. 1-16, 2018, DOI: 10.3390/ijerph15050918.

[18] A. U. Zogara, "Screen Based Activity dan Status Gizi Pada Anak Sekolah Dasar Di Kota Kupang," Cmhk Health Journal, vol. 2, no. 1, pp. 15-19, 2018.

[19] T. Alia, "Pendampingan Orang Tua pada Anak Usia Dini dalam Penggunaan Teknologi Digital," A Journal of Language, Literature, Culture, and Education, pp. 65-78, 2018.

[20] L. L. Hardy, M. L. Booth, and A. D. Okely, "The reliability of the Adolescent Sedentary Activity Questionnaire ( ASAQ ) The reliability of the Adolescent Sedentary Activity Questionnaire (
ASAQ )," Preventive Medicine, no. July, pp. 71-74, 2007, DOI: 10.1016/j.ypmed.2007.03.014.

[21] E. Hoare, K. Milton, C. Foster, and S. Allender, "The associations between sedentary behaviour and mental health among adolescents: a systematic review," International Journal of Behavioral Nutrition and Physical Activity, vol. 13, pp. 1-22, 2016, DOI: 10.1186/s12966-016-0432-4.

[22] S. J. H. Biddle, E. B. García, Z. Pedisic, J. Bennie, I. Vergeer, and G. Wiesner, "Screen Time, Other Sedentary Behaviours , and Obesity Risk in Adults : A Review of Reviews," Springer Science Media New York, vol. 6, pp. 134-147, 2017, DOI: 10.1007/s13679-017-0256-9.

[23] G. Luis et al., "Factors associated with objectively measured total sedentary time and screen time in children aged 9---11 years," Jornal de Pediatria, no. $\mathrm{xx}, \quad$ pp. 1-12, 2018, DOI: 10.1016/j.jped.2017.12.003.

[24] A. Chortatos, S. Henjum, L. Elin, T. Id, L. Terragni, and K. Gebremariam, "Comparing three screenbased sedentary behaviours ' effect upon adolescents ' participation in physical activity: The ESSENS study," Plos One, vol. 15, no. 11, pp. 114, 2020, DOI: 10.1371/journal.pone.0241887.

[25] L. M. Puspita and K. C. Utami, "Sedentary Behaviour Pada Anak Usia Sekolah Di Denpasar Timur," Community of Publishing In Nursing (COPING), vol. 8, pp. 111-117, 2020.

[26] Australian Government Department of Health, "Physical activity and exercise guidelines for all Australians," Australian Government Department of Health, Jan. 14, 2021. https://www.health.gov.au/health-topics/physicalactivity-and-exercise/physical-activity-andexercise-guidelines-for-all-australians (accessed Sep. 03, 2021).

[27] L. K. Chai, K. Rice-McNeil, and S. G. Trost, "Patterns and Correlates of Sedentary Behavior in Children Attending Family Child Care," International Journal of Environmental Research and Public Health, vol. 17, pp. 1-10, 2020.

[28] S. A. Prince, A. Melvin, K. C. Roberts, G. P. Butler, and W. Thompson, "Sedentary behaviour surveillance in Canada: trends, challenges and lessons learned," International Journal of Behavioral Nutrition and Physical Activity, vol. 17, no. 34, pp. 1-21, 2020.

[29] Y. Arihandayani and E. Martha, "Sedentary Behavior of Junior High School Students in Cibinong Sub-District Bogor Regency West Java 2018," Jurnal Ekologi Kesehatan, vol. 19, no. 1, pp. 76-83, 2020.

[30] C. R. Blanco, J. R. Almagro, M. D. Zafra, M. L. F. Fernandez, M. del C. P. Laguna, and A. H. Martinez, "Physical Activity and Sedentary Lifestyle in University Students : Changes during Confinement Due to the COVID-19 Pandemic," International Journal of Environmental Research and Public Health, vol. 17, pp. 1-13, 2020. 
[31] N. Pangesti, I. M. A. Gunawan, and M. Julia, "Screen based activity sebagai faktor risiko kegemukan pada anak prasekolah di Kota Yogyakarta," Jurnal Gizi Klinik Indonesia, vol. 13, no. 1, pp. 34-41, 2016.

[32] A. Ensenyat, N. Serra paya, and L. Sagarra Romero, "Objectively measured sedentary behaviour in overweight and obese prepubertal children : challenging the school," International Journal of Environmental Health Research, vol. 00, no. 00, pp. $1-12$, 2019 ,

DOI: $10.1080 / 09603123.2019 .1609656$.

[33] B. L. Keyes and K. S. Wilson, "Influence of Parental Physical Activity and Sedentary Behavior on Young Children: Considering Time Together," Research Quarterly for Exercise and Sport, vol. 92, no. 3, pp. 311-320, 2021, DOI: 10.1080/02701367.2020.1727405.

[34] G. Oematan, U. N. Cendana, G. Oematan, and U. N. Cendana, "Durasi tidur dan aktivitas sedentari sebagai faktor risiko hipertensi obesitik pada remaja ( Sleep duration and sedentary activity as a risk factor for obesity hypertension in adole ... remaja," Ilmu Gizi Indonesia, vol. 4, no. March, pp. 147156, 2021.

[35] W. N. Putra, "Hubungan Pola Makan Aktivitas Fisik dan Aktivitas Sedentari Dengan Overweight Di SMA Negeri 5 Surabaya," Jurnal Berkala Epidemiologi, vol. 5, no. 3, pp. 298-310, 2017, doi: 10.20473/jbe.v5i3.2017.

[36] L. Lotoski, D. Fuller, K. G. Stanley, D. Rainham, and N. Muhajarine, "The effect of season and neighbourhood-built environment on home area sedentary behaviour in 9-14 year old children," International Journal of Environmental Research and Public Health, vol. 18, no. 4, pp. 1-15, 2021, DOI: $10.3390 /$ ijerph18041968.

[37] R. S. Mayne, N. D. Hart, and N. Heron, "Sedentary behaviour among general practitioners: a systematic review," BMC Family Practice, vol. 22, no. 6, pp. 1-8, 2021.

[38] B. Chandrasekaran, "Sedentarism and chronic disease risk in COVID 19 lockdown - a scoping review," Scottish Medical Journal, vol. 66, no. 1, pp. 3-10, 2021, DOI: 10.1177/0036933020946336.

[39] Y. Yang, J. C. Shin, D. Li, and R. An, "Sedentary Behavior and Sleep Problems: a Systematic Review and Meta-Analysis," International Journal of Behavioral Medicine, vol. 24, pp. 481-492, 2017, DOI: 10.1007/s12529-016-9609-0.

[40] R. Patterson et al., "Sedentary behaviour and risk of all-cause , cardiovascular and cancer mortality , and incident type 2 diabetes : a systematic review and dose-response meta-analysis," European Journal of Epidemiology, vol. 1, pp. 811-829, 2018, DOI: 10.1007/s10654-018-0380-1.

[41] S. Houtan, J. Stewart, and F. Hassani, "Physical activity during COVID-19 quarantine," Acta Pediatrica Nurturing The Child, vol. 109, no. 10, pp. 0-1, 2020, DOI: 10.1111/apa.15420.

[42] A. Iannaccone et al., "Stay home, stay active with superjump®: A home-based activity to prevent sedentary lifestyle during covid-19 outbreak," Sustainability, vol. 12, no. 23, pp. 1-10, 2020, DOI: 10.3390/su122310135. 